\title{
THE EFFECT OF HIGHIVERSUS LOW PRESSURE ON THE PNEUMATIZATION OF THE MASTOID CELLS. AN EXPERIMENTAL STUDY
}

$$
\text { By }
$$

\author{
K. OGAWA
}

\section{From the Department of Oto.Rhino-Laryngology, Nagasaki University School of Medicine (Director: prof. T. Goto)}

It is generally recognized that the extent of pneumatization of the mastoid cells may be genetically determined. On the other hand, otitis in infancy has been considered an inportant factor associated with underdeveloped mastoid cells. The author and $T$. Goto do not agree with this opinion and have believed that the development of the mastoid cells may be genetically determined.

Recently T. Goto and S. Shibata have reported that there is a marked fibrosis in the lungs of skin divers and limited development of the mastoid cells. From these results they suspected that pressure might have some influence on the extent of pneumatization of the fneumatic cavities, the lungs, accessory sinuses and mastoid cells.

The author has planned to study experimentally the effect of pressure upon the mastoid cells. For this experiment he constructed a pressure tank, in which constant pressure could be maintained at 3 atmospheres or at a pressure of $2 / 5$ of an atmosphere. The oxygen was insufflated into the tank under constant pressure.

The animals used for this experiment were young chickens 7 days old at the start of the experiment. The chicken has well-developed mastoid cells and its mastoid cells develope very quickly. The experiment was carried out on the two main groups, namely the high pressure group and the low pressure group. Chickens in each of the groups were placed in the tank for 2 hours daily. In each of these groups the observation was made at the end of 30 and 60 days on 15 chickens in each subgroup. During these experiments chickens have not shown any gross changes. The development of the chickens was not delayed compared with the control chickens. But the mastoid cells of each group were markedly underdeneloped. The septae of the air cells were thickend and the lumen of the cells were decreased in size. The hight of the linning epithelial cells was increased and the subepithelial tissue was fibrous and thick. Residual cartilage tisstie was found. The microscopic appearance of the air cells in chickens exposed for 60 days to high and low pressures are similar. The normal process of development, in which leucocytes infiltrate the subepithelial tissue, macropgages cause bony resorption, and the epithelium proliferates causing an increase in pneumatization, is delayed.

These findings indicate a delay in the development of the mastoid cells. The findings in the mastoid cells of chickens in the two groups were similar, whether they exposed to positive pressures or negative pressures. The animals exposed for the longer time period (60 days) revealed only a slightly increased limitation in the development of the development of the mastoid cells than seen at the end of 30 days. 


\section{高圧・低庄下の中耳蜂窠発育に及ぼす影響に}

\section{就ての実験 的研 究}

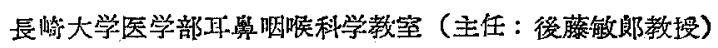

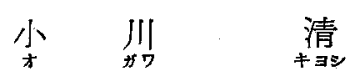

目次

I. 緒論

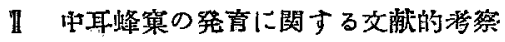

III 研究方法

N 研究成縝

1) 肉服的所見

2) 租織学的所見

$V$ 総括並に洘按

VI 結 論

VII：主恐交献

\section{I. 緒 論}

科学の進歩に伴い，人類の生活環境㥩しく変化し， 高王あるいは低圧環境の下に活動しなければならない状 態となつた・特に近年そうした異常環境における生活の 問題が医学に課せられた課題となつてきた。大気の王の 変化の下に执疾患としては航空機病，高山病，潜函 病等が既に知られている疾患であって，耳围咽唉科方面

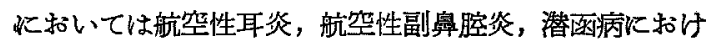
る平衡異常等の問題がある・これ等に就ては研究対绍と して注意されてきたが，その実験の困難なることにも基 因して，根本的問題に就ては不明のるのか゚多い，特にそ の病理組織学的な 問題に就ては殆んど 報告されていな W.

後藤教授は Pneumatisations-lehre の一系として， 高圧・低玨環境に扣いて含気腔（中耳・副䑁腔及び肺を 包含して）がいかなる変化をきたすかを研究中である が，著者はその一部として実験的に中耳蜂巢（乳様䗋 集）の高纴・低仕によるその発充上に及ぼされる影響に 就て研究を試みた。この方面の研究報告としては，後 藤，柴田による潜水漁夫に就ての観察があり，それによ るとかような高圧下に生活する職業のものでは中耳蜂集 扣制状態のものが多く，肺にはレ線的に著明の線維性変 化の認められることが明らかとなつた・この論交の結論 によるとこれ等の変化は高圧が長期作用するためであろ らとされているが，これは実証を要する䦗題として実験
的な研究が残されていたものである・特に中耳䗋染の発 育扣制に就ては，後藤教授は遗伝的因子を特に重視し， 炎症その他による影響を否定した立場にあつたが，高圧 の作用がその発育に影響を及代す重要な条件であること が推測されるよらになつた。この研究の主目的はこの点 の奏証にあるが，又更に研究は副鼻腔及び肺における変 化に対しても拡大される状沉にある。

\section{II. 中耳蜂窠の発育に関する文献的考察}

中耳蜂窠の発育状態即ち Pneumatisation (上下 $P_{\mathbf{n}}$ ) のいかんを判定するために，正常な中耳蜂倮の発育過程 に就ての従来の説を挙げると次のようである.

Wittmaack によると，第 1 期を䄻様洞形成期（生後 1 年）として，第 2 期を蜂黛形成完成期（4〜5才迄）と し，個人の蜂窠形態の決まる時期としました。第 3 期 は，別に名称はありませんが，終生に亘る緩徐なる発育 期を当てついます。

後藤教授及び小林によると，中耳蜂巢の発育忺次の 3 期に分類され，Wittmaack の誤謬が指摘されている.

第 1 発育期 基本的空腔形成期（生後 1 年迄）

第 2 発育期 蜂窼完成期 （青春期迄）

第3 発育期 含気化充実期 （終生）

第 1 発育期は側頭骨内に骨の完成之共に，将来空腔と なるべき部位に胎生組織にて充された部分ができ，その ららに鼓公に接属して含気化された小洞，即ち Antrum ができる時代である.

第 2 発育期はその個人特有の蜂窠の形態が構成される 時期であつて，求心性 konzentrische Pn. と共に遠心 性 exzentrische Pn. に強い発育が行われる.この時期 を Wịtmaack は 4〜 5才迄としているが，この年令の 時期に 発育上の 劃期的な一線を引にことは困難であつ て，青春期迄とするのが妥当であるとされている.

第 3 発育期は空腔の改变とその㹡大は主として蜂窠隔 壁内において行われる時期 interstitielle Pn.で，その 発育は極めて緩慢であるが，終生に亘るものであるとさ れている. 
炊に中耳蜂㮤の 発育を組織学的に みると，胎生 3 カ 月，耳管の侵入により鼓膜の後方に狭い間㩐が認められ る.胎生 5 カ月, 鼓室膑の輪廓がや>明らかになり, 空 腔に相当すべき間吵はその大いさを增すが，大部分の鼓 室腔は 胎生組織により 充たされている. 胎生週令の 進 むに徉つて，この鼓堂間隐膑の㹡大之共に鼓宝爱方の myxomatös な胎生組織で充たされた骨腔も搪大し，新 生児では側頭骨内の迷路㲄を团守部分に広く拡大してお。 り，myxomatös な組織内には将来蜂窠壁となる可き骨 梁 Balken が多数散在して見られ，胎生組織腔つ中心 部には含気腔の侵入が見られる・この時期では䗋笨の上 皮下組織は非常に厚く，胎生組織で充たされている・こ の組織は発育と共に，次第に成熟し，線維化すると共に 吸収されて縮小してくる・同時に骨梁においては破骨沺 胞炕上る䆟状吸収 lacunäre Resorption が見られる。 特に外皮質に向つた方向の骨梁の内側に著明である・他 方吸収部の反側の骨梁では骨の谱殖も盛んに認められ， 䈑状吸収による吸収部位へは結合織の侵入が見られこ れに伴って上皮細胞は陷凹し，空腔するい、空腔となる べき間隚の拡大が行われる・かくして蜂窠の掋大及び改 变は求心性，遠心性に行われ，mucoperiostal 上上皮を むつ中耳蜂笨が完成される・これが所謂「含気化機転」 である.この含気化機転に伴つて現れる組織反応が所謂 r含気化浸潤」，即ち 新生淏及び 胎生末期汇 著朋にみら る>炎症绿の細胞浸潤である・これは Aschoff により “Fremdkörperotitis”として紹介され，又 Wittmaack により “latente Säuglingsotitis”と呼ばれてい たものである・この異物的刺㦸原としては羊水の内容物 が考えられていた・しかしこれは重大な誤謬であって， 後藤教授門下゙の一連の不究によつて,この炎症像細胞浸 飦は全く生理的なるのであり，含気化活動を現わしてい る組織反応であり，及その含気化過程にお活る中間的物 質の吸収機転であり，骨含気腔成立上の特異なる現象で あるとしている。

上述の含気化機転及び含気化浸潤は胎生末期より青春 期頃まで，即方第 2 発育期までが最す旺盛であって，こ の時期までに蜂郓の形態が完成される・それ以後の組織 の活動は緩慢であるが，終生に亘つて行われ個人特有の 蜂柋の構成がみられるむのであるとした・これ等に就て の詳細は関俰交献を参考尤れ度い。

鳥類の中耳䗋窠に就ては，1939 年，指宿は鳥類は極 めて良好に発育した多数の䗋䆞を有し，人類の乳嘴蜂染 系統と酷似していると述べている・教室の楖野によれ
ば，鵎におけるPn.の形成は極めて速かにして，䀒化 後6時間では殆んぞ完成の域にあるため，Pn. 形成の初 期の状態を観察するためには，瞬化前に遡らなげればな らないと述べている。

鳥類の中耳蜂㮤の発育に就ては，山下゙の樢に搮ける請 細な研究がある。それ体ると，䁔化前 24 時間に抢い ては，沜の胎仿の頭蓋は殆えど軟骨であつて，鼓室及び その副室（第 1、第 2，第3副室）か形成せられているだ けであって蜂窠の形成は認められない.そして鼓室及び その副荎性頭蓋の犬いさに比して非常に大きい.鼓室粘 膜任外下部に䚺いて，一部重層扁平上皮を認めるが， 和」をね単圈の扁平あるいは股子状細胞で被覆せられ， また副室粘膜は単層扁平上皮で被っれ，何れも上皮下結 合織は厚く，多数の小血管の存在を認める・この頃から 急速に蜂宣形成が行われるのであって，即ち頭蓋各部よ り較骨の化骨が開始せられ，時日の経過と共行周团軟骨 内に進展する・これに平行して蜂笨はその既化骨部に各 副室・中耳腔怔及び耳管間を基点として漸次形成せられ る・即ち化骨により形成せられた海綿様骨質は粘膜下に 接した骨梁がところごころに打いて，破骨細胞により破

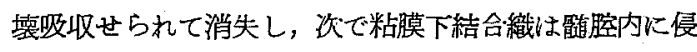
入しきたり，固有週細胞は渐沉退行を始わ，終に全く線 維檤を形成する上らになる・その後再び線維䯣も吸収せ られ，粘膜は歌腔内に没入しきたり，副室表面は種々な る形熊の筧入あるい忯空洞を形成し，遺残骨梁部は副 室内に突出する・かくして各䯣腔は順次線踓酭を形成す ると共に，空洞即ち䗋窠の数を増すのである・かくの如 〈䗋笨は率化後時日の経過と〉もに化骨の進展に平行し て，既化骨部より次第に形成せられ，三半規管鼓腹部は 睬化後 12 日目に全く蜂㮤をるつて困繞せられ，第 1 ，第 2, 第 3 副室からの各蜂窠は互に澺命し交通し，30日目 に至り各蜂窠群はほડ゙完成せられ，名蜂笨壁表面は骨膜 とも粘膜とも判別困難な mucoperiostal な上皮で被覆 せら礼るようになる・しかしこの時期では蜂䆞壁はなお 厚く，海綿様骨質の性状を有寸るものも各所比見られ， 且各蜂窠壁には少量の線維䯣の遗残附着するのを認め る. 爾後蜂笨の形成は漸炏行われて, 中耳蜂粢の拡大と 共炕䗋笨臨骨質の硬度を増し，骨壁は菲薄となり含気性 が増犬される・蔇化後 10 力月の鵎の中耳䗋窠では線維 䯣もすべて消失し，蜂案壁は全く菲薄となり，頭蓋骨の 大部分は含気性蜂黛亡なる。

以上より鳥類の中耳蜂蓄の発育を人類のそれに比較す るとき，その䗋粱の含気化機転は人類の含気化機転に上 
く似ており同一の過程に扔いて行われるのであるが，人 類においては，新生児の側頭骨は既に海綿橡骨質の性状 を有し，将来含気化されるべき部分が胎生組織で充たさ れているのに対して，鳥頪では孵化直後沈いては，頭 蓋骨は大部分軟骨であり，軟骨組織が化骨されて海綿様 骨質となり始わて蜂笨形成が行われ，線維轋胵の部分が 極めて少い点は人類とはや今趣を異にしている・蜂集は その発生起部より次第に外周に向つて発育する, と共に， 蜂巢の隔壁においても含気化機転が行われるが，求心性 の発育の認められない点は人類の場合と異なる。

\section{III. 研究方法}

先つこの研究の目的に適するように, 加圧及び減圧用 の 0.8 立方米のタンクを作製した (写真 1 ，図 1).
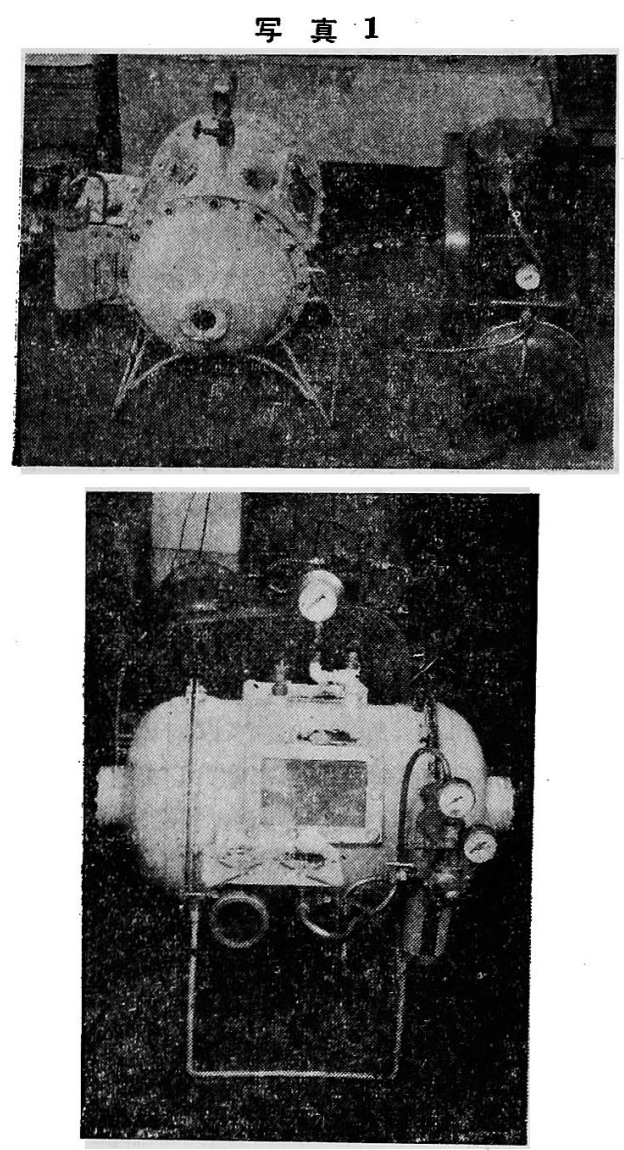

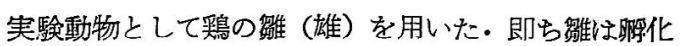
後7 日目のむのを対照群，加圧群及び減圧群の 3 群に分 け，夫く 20 羽， 30 羽， 30 羽計 80 羽を用いた。

加圧群には表1のよ5に，タンク内を1気圧（水梁
図 1 実験用讱圧及び減圧タンク模型図

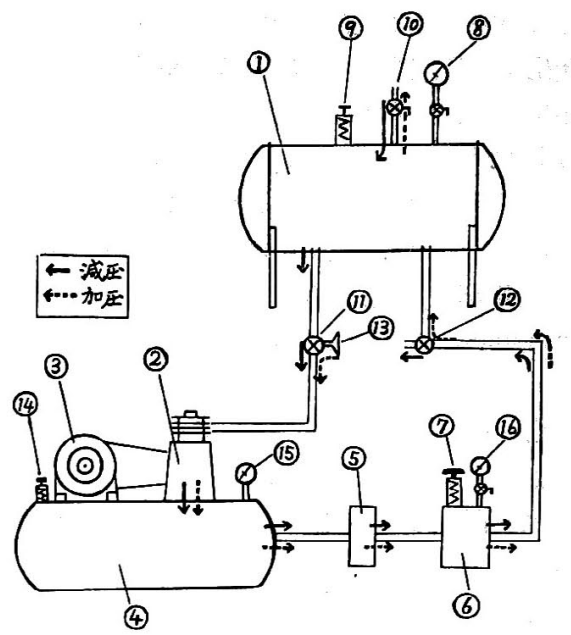

(1) 扣压・減圧タンク

(2) コンプレッサー争

真空ポンプ (3) モートル

(4) エアータン

ク) (5) 空気清淨器

(6) 压力調節器 (7)
調節ハンドル
(8) 真空計
(9) 安全弁

(10) 喚気用ニック (11) 加圧・減圧切㮞用三方

ニッタ (12) 加圧・減圧切換用三方ニック
(13) 空気清浮器
(16) 压力計
(14) 安全弁
(15) 圧方棓。

$10 \mathrm{~m}$ に相当する）加圧した環境に夫る 30 分，60 分， 120 分入れた. 4 日目からは 2 気圧（水深 $20 \mathrm{~m}$ に相当す る), 7 日目からは 3 気圧（水樑 $30 \mathrm{~m}$ に相当する）のタ ンク内に入れ，10日目からは毎日 3 気圧のタンク内に 2 時間入れた・加圧の方法として，急激なる圧の変化に伴 う諸種の障害，特に squeeze を避けるために，大気圧 より 3 気圧加圧する場合には20 分かけて 階段状に徐々 に上昇せしめ，文大気圠に下降せしめるときす，同様に 徐くに行つた.

加圧 3 気圧の場合，モートルに装置してある自動調節 器により，ェアータンク内の圧が 4 気圧に上ると, 自動 的に電流か遮断されてモートルが停止し，実験用タンク 内圧が3気圧より以上に強く上昇することを防ぎ，3気 圧に下降すると再び自動的にモートルが作動するように 作られてある・従つて圧力調節器のハンドルを適宣の位 置に廻し，実験用タンク内の王を 3 気圧に調節すると， 所要の時間内は 3 気死を持続することができる・酸素欠 そ，温度上梨をできるたけ防ぐため排気口より所定の圧 の下で，持続的に換気が行われるよらに作られてある。

低代群も表 1 のごとく徐々に減圧せしめ，10日目か 
ら毎日 2 時間， $300 \mathrm{mmHg}(5000 \mathrm{~m}$ の上空に相当する） の減圧タンク内に入れた・低圧の場合も階没状に減圧し て，常压に復せしめるまでには 20 分を゙要するようにし た・

\begin{tabular}{|c|c|c|c|}
\hline & 加压群 & 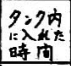 & 減㕵群 \\
\hline $18 \mathrm{O}$ & 1气原 & 30त & $-100^{n+m / 2}$ \\
\hline 2 日日 & " & 60分 & " \\
\hline 38自 & " & $120 \mathrm{\lambda}$ & $"$ \\
\hline 48目 & 2 与下: & 30分 & $-200^{-1-n h}$ \\
\hline 5 日目 & " & $60 \hat{\gamma}$ & " \\
\hline $68 \mathrm{O}$ & 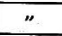 & 60 分 & $"$ \\
\hline 78 目 & 3氛死 & 30 方 & 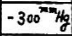 \\
\hline 8 副 & $"$ & $60 \%$ & $"$ \\
\hline 98目 & $"$ & 60今 & $" 1$ \\
\hline 10 日目 & $"$ & 120分 & " \\
\hline
\end{tabular}

鷄の飼盖には混合飼料，野菜不び水を与えた・瞬化後 30 日目までは 1 日 5 回，それ以後は 1 日 3 回の割合と した・実験開始後 30 日目の雛を，対照群 10 羽, 加圧及 び減生群を各 15 羽ら゙断頭，残りの雛を 60 日目に断頭 し，フォルマリン固定，フォルマリン加硝酸脱灰あるい は塭酸による電気脱灰法にて脱灰を行い，パラフイン及 びッェロイヂン包埋にて外耳道にほざ垂直なる連続切片 を作整，へマトキシリン・エオヂン重染色，一部ワンギ ーソン，マロリー染色を行つた。

\section{IV. 研究成績}

1) 肉眼的所見

a) 発育 全身的発育に就ては，加圧及び減圧 30 回の 炛も, 加圧及び減圧 60 回の雛も共に, 対照群と比較し て全く差異を認めなかつた：写真（2）は加圧质び減圧 60 回の雛之睬化後 67 日目の対昭群の雛の 発育を示した もので，肉眼的に羑異を認め得ない。

\section{写 真 2}

対照（那化後 67 日）

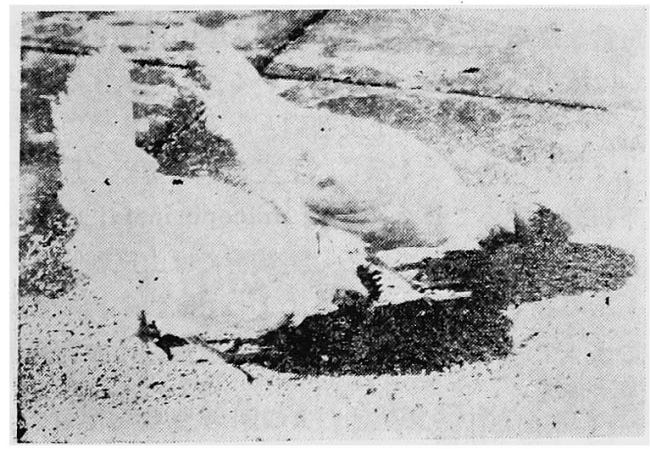

加压 60 回（瞬化後 67 日）

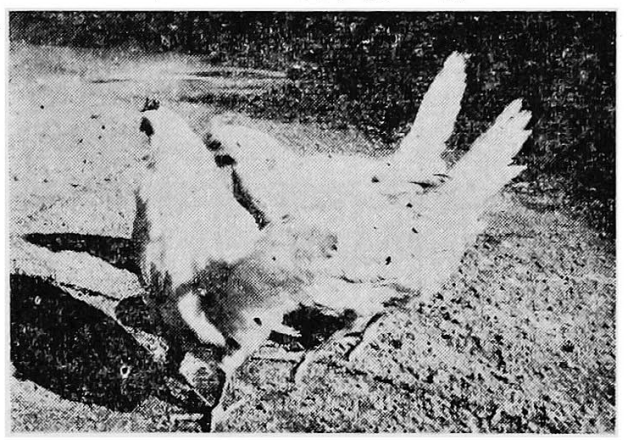

減压 60 回（睬化後 67 民）

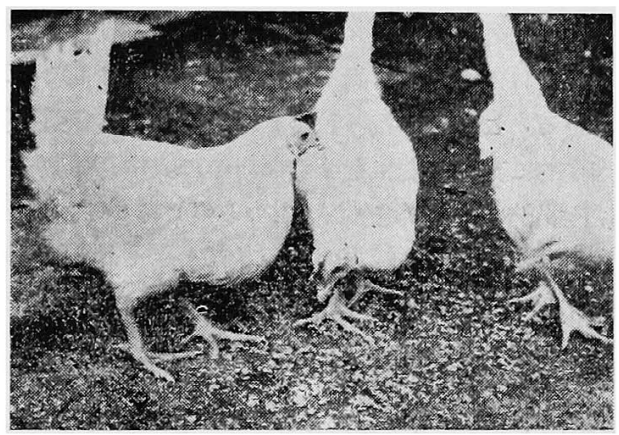

写 真 3

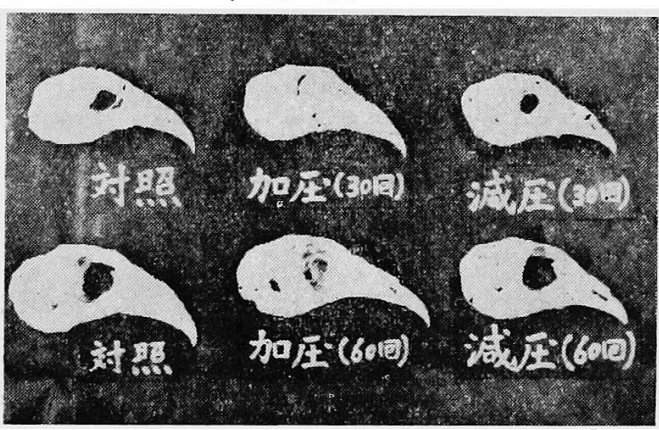

頭蓋の発育に就ても，写真·(3)のごとく肉腿的に刘照 群と矢鈳群との間に，殆んど美異を認めない，しかし頭 蓋骨の横径，䟻径を測定してみると，表 2 のごとく笑験 群に壆度なる発育障害か認わられる・横径は外耳道の上 縁を通り眼简の後縁と頭蓋骨の後縁とを水平線で結えだ 長さであり，縦径は外耳道の後緑を通り頭蓋骨の上緑上 下縁を垂直に綕んだ長さを選んだ。

b) 中耳蜂窠文び個々の蜂窠の大いさ

論交泭図〔1〕はそれぞれ実験開始後30日目，60日 目の実験群及びその対照群の中耳蜂窠を示したものであ 
表 $\quad 2$

\begin{tabular}{|c|c|c|c|c|c|c|c|c|c|c|c|}
\hline \multicolumn{4}{|c|}{ 剂 照，群 } & \multicolumn{4}{|c|}{ 加 厓群 } & \multicolumn{4}{|c|}{ 減 坒群 } \\
\hline a翻号 & 船化拉 & 横徍 & 新变径 & 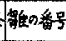 & 摡化徙 & 横洤 & 縱徒 & 知隹の畨号 & 甪化摞 & 横徺 & 织径 \\
\hline 7 & $37^{\circ}$ & 17 & 24 & 21 & 37 व & 17 & 24 & 51 & $37^{8}$ & 16 & 23 \\
\hline 2 & 4 & 17 & 24 & 23 & 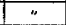 & 16 & 23 & 52 & 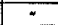 & 17 & 24 \\
\hline 4 & $\Rightarrow$ & 16 & 23 & 24 & 7 & 17 & 23 & 55 & 4 & 16 & 23 \\
\hline 5 & $"$ & 16 & 23 & 26 & 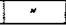 & 16 & 23 & 56 & $"$ & 16 & 23 \\
\hline 7 & $"$ & 17 & 124 & 28 & $"$ & 16 & 23 & 58 & $"$ & 16 & 23 \\
\hline 9 & $"$ & 17 & 24 & 29 & $\Rightarrow$ & 17 & 24 & 59 & $n$ & 16. & 23 \\
\hline 10 & " & 17 & 24 & 31 & * & 16 & 23 & 61 & $"$ & 17 & 24 \\
\hline 12 & 679 & 21 & 27 & 38 & 678 & 19 & 26 & 65 & $67^{8}$ & 18 & 25 \\
\hline 13 & 11 & 21 & 27 & 39 & $"$ & 20 & 27 & 67 & $\because$ & 19 & 26 \\
\hline 15 & $"$ & 20 & 26 & 40 & $"$ & 20 & 26 & 68 & $"$ & 20 & 26 \\
\hline 16 & $"$ & 20 & 27 & 41 & 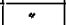 & 20 & 27 & 69 & 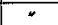 & 19 & 26 \\
\hline 17 & " & 21 & 27 & 43 & $"$ & 20 & 26 & 71 & - & 20 & 27 \\
\hline 18 & $"$ & 20 & 26 & 45 & 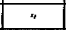 & 19 & 26 & 72 & $"$ & 20 & 26 \\
\hline 19 & $"$ & 20 & 26 & 46 & $"$ & 19 & 26 & 73 & $"$ & 19 & 26 \\
\hline 20 & If & 21 & 27 & 48 & $"$ & 20 & 27 & 75 & $"$ & 19 & 26 \\
\hline
\end{tabular}

る・これは外耳道にはざ直角なる垂直連続切片で，骨性 外耳道入口部よりほら゙同一なる距離仙ある断面の中耳蜂

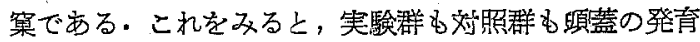
が肉眼的に殆んど变化を認めないのに，中耳蜂案の大い さは肉眼的に著朋な変化を認めるのであって，加生 30 回，60回の觹の中耳蜂笨の大いさははそれぞれ対唄群のそ れに比して小であり,㕛個々の蜂笨の大いさむ小である. しかし加圧群と減压群との間には全く差異を認めない。

c) 蜂案隔壁の厚さ

附図〔『つに示されているごとく，実験群即ち加圧群， 減压群は対照群に比し，蜂粱壁の骨梁が著明に肥厚して いる. 又頭蓋表面の骨の肥厚も著明である・対照群化打

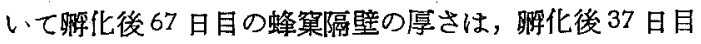
のこれに比して著朋に菲薄になつているが，笑験群に打 いてはこの峏時期の間に殆んど羑異が認め得られないの みでなく，加压群と減圧群との間にも差異を認めない．

\section{d) 鼓 膜}

加生群の鼓膜を減王群のそれに比較するに，その位置 は両群の間に殆んと゚変化はなく，又対照との間にも変化 なく，著朋な鼓膜の陌凹，凸出は認められず，又鼓膜の 破裂も見られなからた。

$$
\text { 小 括: }
$$

実駼群と対照群との間隹認められる著明な変化は，肉 眼的に頭蓋の発育に变化を認めないにも拘らず，実験群 が中耳蜂窠の広り，個々の蜂窠の大いさが小であり，且 骨梁の著明なる肥厚が認められた・即ら著鹏な発育抑制 が認められた・実驗30回の群と実駰 60 回の群との間に は著明な差異が認められなからた・刘照群では蜂窂隔壁 は瞬化後 37 日から 67 日に正んで著しく菲薄になること が認められたが，実験群では，变化は既に30 回加生群 (37 日目) のものにおいて著明に現れ，关れ以降の加圧
に対する変化は肉眼的には著明に認められていない。

2) 組織学的所見

眀化後 7 日目の中耳蜂集の発育をみると，附図〔四》 に見られるごとく中耳蜂集の形態は性ざ形成されている が，軟骨組織が諸所にみられ，中耳腔の周囲は未だ軟骨 にて囲まれている. 文蜂窠の周辺部では未気胞化の原始

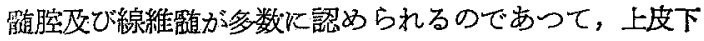
に接した線維酭のところでは，破骨細胞による骨の窝状 四収, 毛細管の增殖及び少量の円形細胞浸潤が認められ る。

睬化後37日目の解の中耳蜂窗の形態は殆んぞ完成さ れているが，未だ中耳腤の周困には軟骨組織が認めら れ，化骨とつもに蜂窠の形成が見られる・蜂巢の周辺部 では僅かに線維髓が認められるに過ぎない。

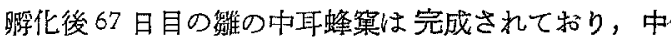
耳腔の 周团の 軟骨も殆えど化骨され，合気化されてい る・蜂笨の周辺部にも未気胞化の骨咀組織は全く認めら れない。

睬化後 10 カ月の鶏の中耳蜂窠は，含気化が周辺と むに蜂窂隔壁間に乱いても行われ，高度の含気化が示さ れている(附図〔吕)).

a) 中耳䗋䆞の発育度

先づ加圧 30 回の雊の中耳蜂巢の発育度を対照群のそ れに比較してみると，大いさは前述したごとくであり， 軟骨の化骨状態は，刘照群では中耳胵の周囲以外には軟 骨を認めないが，加压群ではその他の部分にもなお僅か

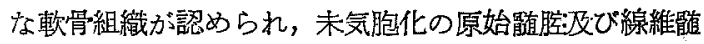

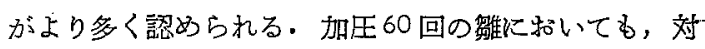
照群では中耳畆周囲に殆えど軟骨は認められないが，加 王群ではな洺くの軟骨組織が諗奶られる・又蜂涂の周 㧅部に線維觬が認められ，淢王群においても全く同様で あった (附図 $(\mathbb{I I}, \mathbb{N})$ ).
b) 上
皮

正常な蜂策ではその初期《はや〉厚い扁平上皮細胞あ るいは骰子状の上皮で被われているが，含気化の進むに 従つて，極めて扁平恃上皮沺胞となるのであつて，対照 群ではこの状態をよく示し，上皮細胞は極めて扁平で上 皮下組織は極めて薄く，所謂 mucoperiostal の上皮と 云われる状態を示している・実験群では上皮細胞はいず れもその高さを堌し，ところによつては骰子状の上皮細 胞のむつである・上皮から見ると上皮沺胞の成育抑制の 状態である・

c）上皮下組織 
莭化後7 日目の中耳蜂窠では，含気化された䗋曧壁の 上皮は上皮下組組織が吸収されて既に mucoperiostal の上皮となつているが，その周縁部にはなほ僅かな線維 鹃が見られ，上皮下にも幼若な結合織の厚い層が存在 し，その部分では骨梁の简状吸収，毛細管の増殖及び少 量の円形細胞漫潤が䍿められる。

餒化後 37 日目及び 67 日目の対照群の中耳蜂案では， 上皮下組織は薄く，広く mucoperiostal の上皮となつ ているが，中耳蜂窠の周縁部の蜂巢䧣壁に峉いてはや」 厚い上皮下組織を有する部分も見られる。瞬化後 10 力 月の鶏では，蜂窠の上皮は極めて薄く上皮下織賞は殆ん ど諗め得られない程度である（附図〔III)）。

加圧君ではいずれも上皮下結合織の肥厚が認められ，

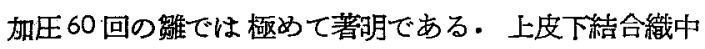
には毛細管の増殖が認められ，又骨梁に接して造骨細胞 の堌殖が認められる・又時に軽度の出血も認められた。

墄王群も加圷群とほら゙同様の所見を是し，差異を認め 得られなかつた（附図 (VJ)。

\section{d) 䗋窂隔壁の厚さ}

対照群において，蜂窩隔壁になほ皮下結合織を有する ところでは，緩慢ではあるが含気化が行われており，即 ち骨の简状吸収部には結合織の陷入が行われ，それと共 に上皮も陌入し，骨梁の菲薄をきたすと共に䗋巢内腔の

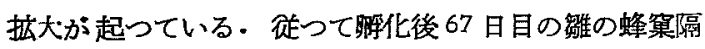
壁は 37 日目のそれよりも更に愿さを減じており，各蛏 窠膑る拡大している.

加环群では骨梁の厚さは対照群のそれに比して著明に 肥厚しており，文頭蓋表面の骨す著朋に肥厚している. 加圧 30 回と加圧 60 回の雊の骨梁を比較しても，その間 は殆んど差異は認め得られないが，この点は対照群と著 しく異つている・

減环群においてす全く同娽の所見が認められ，両群の 間には差異は䍿められ得なかつた（附図〔【Iつ）。

e）骨の堌殖

対照群において，中耳蜂粕の周緣部をみると，薄い上 皮下組織內に骨に接して少数の造骨細胞が認められ，倬 かではあるが骨の堌殖を示している・中耳蜂集を囲む頙 蓋骨においては，学膜下に造管細胞の層があり，盛んな る骨の増殖を示している。

実稑群に拈いては，対照群に比して造骨細胞の増殖が

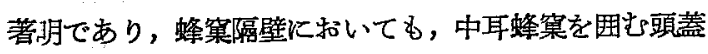
骨においても明らかに骨の肥厚が諮められる・次に奏験 群における実験 30 回のるのと実験 60 回のるのを比較し
て，後者に肥厚がより強く認められない点は一見不審に 思われるが，これは，対照群に゙比すれば僅かではある が，骨の吸取が行われているためであると思われる。

この骨梁の肥厚している状態を発育の㧕制と見做すと きは，30 回加圧時期の状態よりも60回加圧の時の方が より強い発育抑制状態を示さないことは当然の現象であ る.この発育上の状態は同時期の刘昭と比較してはしめ て意義があるのであつて，60回加圧即ら卯化 67 日目の 加仕例を 67 日目の正常群と比較するとその間の差異方 30 回加生例とその対照君との間より著朋なことが知ら れる。

\section{f) 骨の吸収}

対照群では，周緑部の上皮下組織の存在する蜂集壁に 和いて，僅かではあるが窩状吸収が行われており，腔内 に少数の円形細胞浸潤が認められる・特に頭蓋骨の蜂巢 に面した上皮下には，骨の简状部に菱形の破骨細胞が認 められ，盛九なる䆚状吸収像を示して括り，上皮下にあ るいは膑:内に遊離骨片が諗められ，その周困には著明な る細胞浸潤が認められる(附図 (N) ).

実験群においては，著明なる所見は蜂㮤の上皮下に結 合織の著明な堌殖が認められるが，細胞の浸潤は極めて 弱く，頭蓋骨の皮質に向つている蜂窝骨梁にも，窩状部 が少なく破骨細胞による骨吸収の緩慢であることを示し ている・盛んなる含気化機転の座成物と見られる遊離骨 片る認められないここれ等の所見は加圧群と減圧群との 間には差異は認められない。

\section{小 括 :}

夷験群と対照群とを比輘して認められる著朋な变化 は，蜂穼の上皮細胞層の高いこと，上皮下結合織の堌殖 肥厚, 造骨細胞の堌殖を伴つた骨梁の肥厚及び含気化機 転これに伴ら含気化浸潤の緩慢さとその之しさとであ る・又対㫟群では既に軟骨組織の存在しない部位に，実 駼群ではなほ軟骨の残存が認められ，対照群に見られた ような遊離骨片の存在も見られない，加生君も減仕君子 同様の変化を示し，差異を認めることはできなかつた。 これ等の現象は一言にして云えば蜂窠発育の著しい遅延 又は抑制であつて，Pneumatisations-hemmung の所見 に相当する・しかるこれ等の変化が減圧・加仕の両群之 むに認められる点は予測しなかった知見である・自然の 圧の変動とい5因子に刘する反応の代方は一つであるこ とを示している。

\section{V. 総括並に考按}

Pn.-hemmung の成因に就て 
人類に 見られる中耳蜂巢の 発育抑制 Pn.-hemmung なる狩翼なる現象の成因に就て今日迄種々論ぜられてき たが，これを交献的に考察してみると，二つの学锐に分 ける事ができる・その第一は遗伝的因子を主因とする先 天説である・即ち Schwarz u. Eysel (1873), Wildermuth (1887), Bezold (1882), Mouret (1913) は Pn.-hemmung なる現象は，個人的差異による遺伝的な あのと考觉た。

Wagner (1921) は Pn..hemmung の原因は，頭蓋骨 の硬軟によるとし，又 Turner u. Porter(1922) は人種 的研究より頭蓋骨の型体に就て，長径頭㰜に Pn.hemmung が多いことを指摘した。

後藤教授門下の一連の研究では, Pn. の型体が全く遗 伝体質的なものであることをし線学的に又組織学的に証 明した・教室の光增は家系的調查より Pn.-hemmung の遗伝型式に就て研究し，Pn.の型体は遗伝的関係を有 し，抑制因子は優性因子であることを明らかにした・

Albrecht, Schwarz 等は双生罗の研究より Pn.-hemmung は遗伝因子によることを発表した・本邦に打い ても田中 (1926), 下田 (1932), 岡崎 (1936) 等はこの 説を支持している.

第二は炎症を主因とした後天説であって，これに就て は Schüller (1928), Van Gilse (1926), Albrecht, Grahe (1728) 等の研究があるが，後天説の主体をなす ものは Wittmaack の炎症説である.Aschoff (1897) が新生児の中耳䗋笨の粘膜に $85 \%$ に 円形細胞浸潤を諮 め，その後 Wittmaack (1918) はこの 円形細胞の浸潤 を羊水による異物性炎症とし，これに latente Säuglings-otitis と名付仔，これをPn.-hemmung の原因であ るとした・由来炎症とPn.-hemmung とは密接な因果関 係を持つあのと考えられることつなり，Pno-hemmung は炎症によつてくるむのであるとの説が現在も広く信ぜ られている・しかしながら後藤教授閒下の一連の研究に より，この新生罗に見られる炎症様所見は生理的なるの であり，含気化機転に伴つて起る含気化浸潤即り含気化

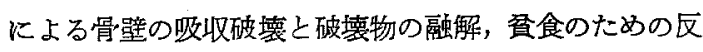
応であるとした・従つて後藤教授の Pn.-lehre から見 れば，Wittmaack の炎症説は当らないが，Aschoff 以 来の異物性の炎症という意味は肯定することができる。 但し，この場合の異物となるものは羊水内容物でなくし て，含気化のための組織の破壊吸収による成産物自身で ある点が異つている。

炎症が Pn.-hemmung の原因とされた理由は，慢性
の炎症によつて䗋菒の骨壁は堌殖し，更に進んで蜂案を 埋めつくすむのであるとするのである・教室の重野は慢 性中耳炎の患者优て，発病後 10 年以下，20 年以下， 20 年以上の炎症持続の 3 群に分けて，これを組織学的 に観察し，中耳䗋僧の骨壁は sklerosierung を起すこと なく，粘膜の変化とす関係なく，緩慢であるが個性的， 生理的な变化を営むるのであるとしている，従つて現 在，中耳䗋巢の発育抑制は，主として遺伝的因子による るのとの考が信じられている.

しかしながら最近，既に前揭の後藤，柴田の潜水漁夫 に和ける頭部含気腔の変化についての研究で, 潜水漁夫 の中耳蜂䆩のレ線像で Pn.-hemmung が極めて多い. 即ら抑制型が 82\%，良好型が $18 \%$ であつた。教窒にお ける一般人に就て行つた統計では抑制型が $14.5 \%$ ，良好 型が $85.5 \%$ であり，一般人とは全く逆の関係を示して いる・文隔壁の著明な肥厚が認められ，䗋策発育良好な

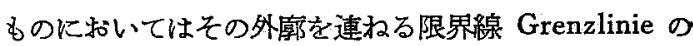
肥厚が極好て著朝である。これらの所見から裸潜漁夫に 見られる中耳蜂案の Pn.hemmung の状態は単に遗伝 因子のみによる之は考它難く，水圧が関係するのではな いかと述べていたが，この推測は本実験の結果からとの 妥当なことが肯定された。

中耳䗋窂発育抑制 Pn.-hemmung とは

Pn..hnmmung を理解するためには，正常蜂菒の発 育過程を知ることが必要である・これに就ては既に述べ た・即ち中耳䗋窗の発育機転は基本的空腔形成機転之蜂 巢形成機転に依って成り立つて括り，Pn。の良否，その 個人差は，この基本的空腔:の大小と蜂巢形成の強弱とに よつて決まるものである. 㕛中耳䗋集の発育は基本的筀 腚:形成期，䗋集完成期，含気化充実期の 3 期飞分けるこ とができるのであって，Pn.-hemmung は発育の停涩 は緩慢さが主として第二発育期より起つたものである。

これを組織学的にみるならば, Ideal のPn。を持つる のでは上皮下の myxomatöses Gewebe が吸収されて 上苦下層が縮小すると共に，骨梁においては盛んなる简 状吸収が行われ，窩状吸収部位へは結合織の侵入が見ら れ，これに伴つて上皮細胞は宿入し，空腔の掋大が行か れる・文吸収部の反側には，造骨䋎胞の盛んなる堌殖を 示し，蜂窗の発育は遠心性・求性及び蜂菒間性に行わ れる・これが所謂「含気化機転」でありこれに伴つて みられる资症様細胞浸潤がわれわれが仮に「含気化性の 浸潤」と呼んでいたものである・この「含気化機転」の 停止文は緩慢さが Pn.-hebmungである。 


\section{本研究成續の批判}

徭に拈ける中耳のPn.は極めて良好であり，人類の 中耳䗋窼の発育によく似ているのであつて，山下に依れ ば，鳥類は睬化 24 時間前においてて既に基本的空腔は形 成され，人類と異り将来，蜂巢となるべき部位は軟骨で あり，中耳脘及び副堂は頭盖の大いさに比して極めて大 きく，この時期迄が人類の第 1 発育斯に相当するすのと 考党られる・この㥧から化骨現象が急速に進み，化骨に より形成された骨梁はところどころ破骨細胞に上り破壊 吸収せられると」るに他方文堌殖が認められる・胎生組 織内に散在する島嶋状の骨梁片は互に融合してそのうち に線維㖵様の腔を作る。一部には文骨酭が吸収せられて 線維的道となつている部分子存在する・次以線維㨁もやが て吸收されて mucoperiostal な上皮で被われた蜂窠形 成を見るのである。瞩化後 7 日目，37日目，67日目の 中耳䗋窼の発育をみると， 7 日目上り既に䗋菓の形態は 見られるが，軟骨も全く化骨された中耳䗋窗の完成され た状態は 67 日目の雊に見られる・それ以後は悢慢では あるが含気化が行われ，周緑に向つて遠心性に又䗋䆞の 隔壁間に执いて蜂穼間性に蜂巢の拡大，増大が行われ る.この点から蔇化後 67 日頃までが 人類の第 2 発育期 に相当するるのと考兄られる。

本実験忊丁度第 2 発育期に加圧・隇圧が加えられたる のである・

瞬化後 37 日目の対照群では中耳腔の周困に多くの軟

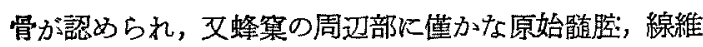
咀が証められ，化骨現象・蜂窂形成が見られる・睬化後 67 日目の站照群では中耳腔の周囲に残存していた軟骨 が殆んど化骨，含気化されており，蜂寨の周辺部にはも

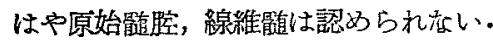

これに対して，加圧及び減圧 30 回の騅のれ耳蜂嫼で は，中耳膑の周囲は勿論その他の部位にる軟骨を認め，

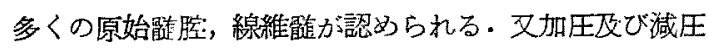
60 回の雛でも中耳腔の周囲には多くの軟骨・を認め，化 骨，含気化が行われている・これは明らかに含気化発育 の抑制を示するのである。

次に刘照群に括いては䗋算の周緑部特に頭蓋表面に相 䴔する蜂笨の上皮下に破骨“細胞による窝状吸収が盛儿に

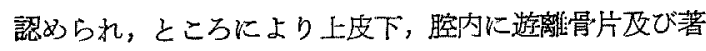
明な細胞浸潤が認められた・㬰験群では简状吸収像，円 形細胞浸潤乏しく，遊離骨片は認められていない。

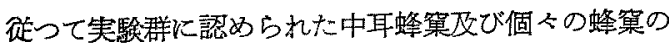
大いさの小さいことは含気化機転の遅延を示するのであ
ク，含気化抑制の所見である。

又蜂䆵隔壁及び頭蓋表面の骨の肥厚は主として胎生結

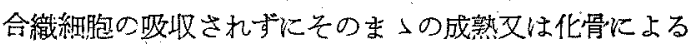
ものであつて，広く兄ると含氮化の発育抑制と見られる が，又これは压に対する骨の反応的肥厚む加つていると 見なければならない。

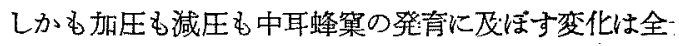
く同一であり，著明な発育抑制の認められることが明ら かにされた。

\section{VI. 結 論}

中耳蜂窠の発育抑制 (Pn.-hemmung) は，主として遗 伝的因子によるものとの考えは，現在広く信じられてい る・慢性炎症によって Pn.hemmung をきさないこ とは，教室の重野によつて確められた・圧の変化が中耳 蛒窩の発育にいかなる变化をきたすかに就ては，先に後、 藤教授，柴田时教授の潜水漁夫に就いての砥究がある。 著者は高王・低圧環境が中耳蜂䆞の発育にいか、作用す るが加圧・減圧用タンク・舀の雅を用いて笑駼的研究 を行い，次のことを結論する事ができた。

1. 高珐環境も低圧環境も中耳蜂巢の発育に 抑制的に. 働いた。

2. 高圧も低圧む刺戟としては同一であつた。

\section{VII. 主要文献}

1) 後藤：Pneumatisationの成立とその臨床，日耳學，

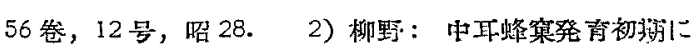
見られる笑症椂所見に関する研究，日悬耳，56卷，11

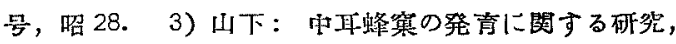

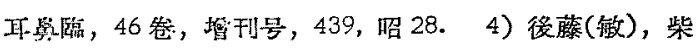

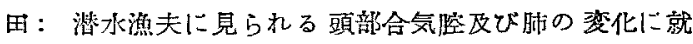

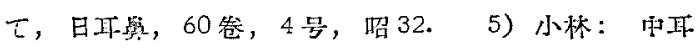
Pneumatisation の生後の発育に関する研究，日耳卢! 57 卷, 2 号, 昭 29.6) 重野: 慢性安耳笑々 Pneumatisations-hemmung の閣溧に関标に就いての租織学的

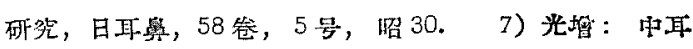

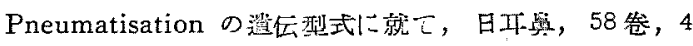
号, 㗁30. 8) 後藤: Sauglingsotitis に就いて, 平

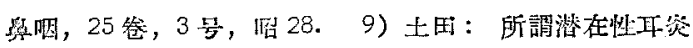

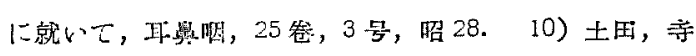

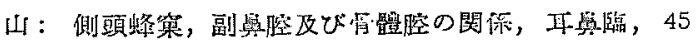
替, 9 号, 昭 27.11 ) 後藤, 柳野: 成人中国蜂穿の

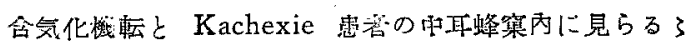
特暴なる所見, 日耳筫 58 管，8号，略30.12）山野

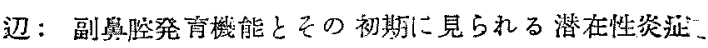


様所見，日耳基，56卷，8号，骝 28.113）柴田：節

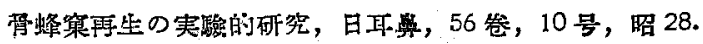
14）橋本，稗田，江崎：家棌上腕骨々髄にまりる含気

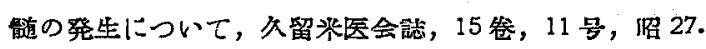

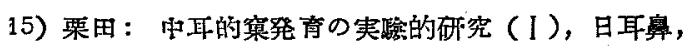

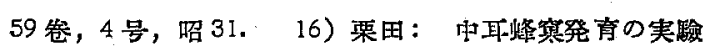

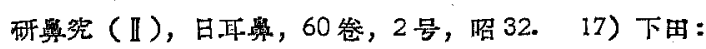

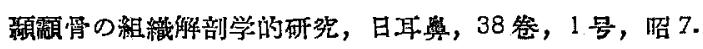
18) 梨本：高気圧による陡碍，医学のおりみ， 24 卷， 2 号，3号，置32.19）緒方：高圧の生体に及ぼす影譩， 熊本医点, 14 悉, $1331 \sim 1342$, 炤 13.20 ) 日下, 山 由, 鄉本：航空性中耳炎に就七，日耳基，58管，4昂， 昭 30. 21) 佐藤，仙石，三沢：航空性副畧腔炎に就 $\tau$, 耳舆胭, 28 卷, 13 号, 沿 31 22) 久保, 吉田:

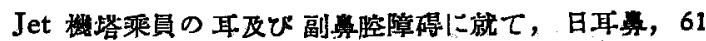

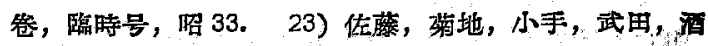

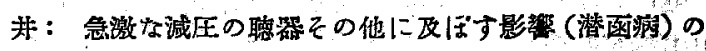
研究, 日耳草, 61 卷, 臨時号, 昭 33. 24) Preysing: Otitis media der Sauglinge, Arch. f, Ohrenheilk. Bd. 61, 1904. 25) Marx H.: Zur Frage der Bedeutung der Mittelohrenentzundung des fruhesten Kindesalters fur sprter, Arch. f.O.N.u.K.-Heilk, Bd. 126, 1930. 26) Aschoff: Die Otitis media neonatorum, Zeitschr. f. Ohrenheilk., Bd. 31, 1897. 27) Wittmaack: Uber die normale u. pathologische Pneumatization des Schlafenbein, Jena 1918.

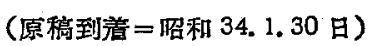




\section{小川論文附図（I）}

対照群，加圧群及び減圧群におりる山耳蛒窠の発官状況

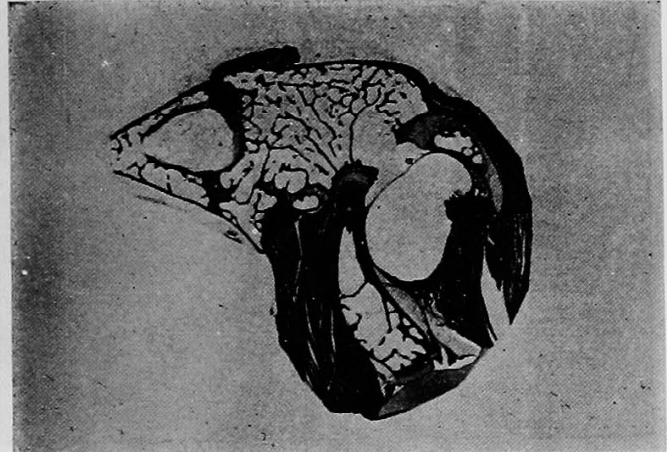

1. 対照（餒化後 37 日）

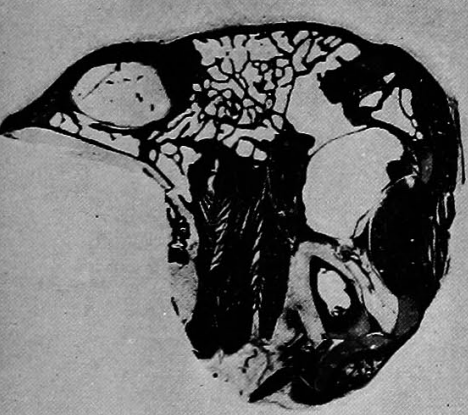

3. 加圧 30 回（卯化後 37 日）

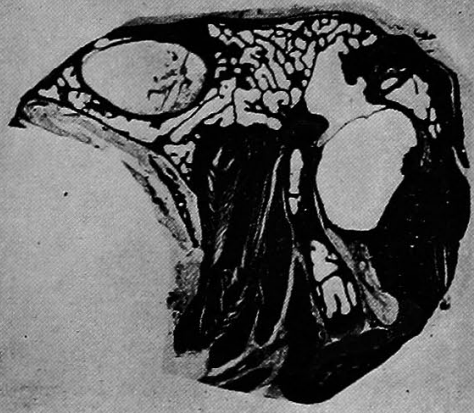

5. 減圧 30 回（孵化後 37 日）

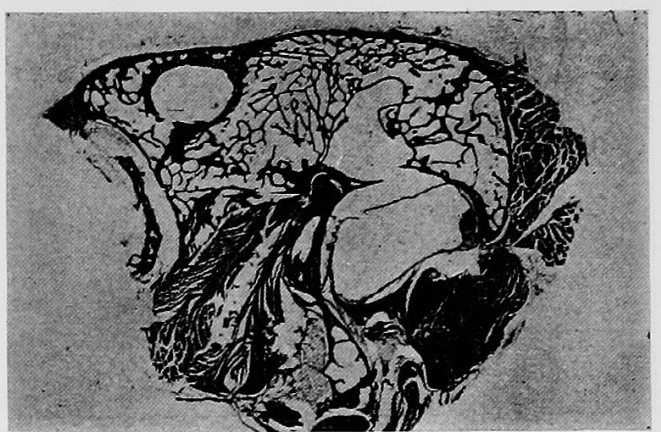

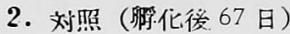

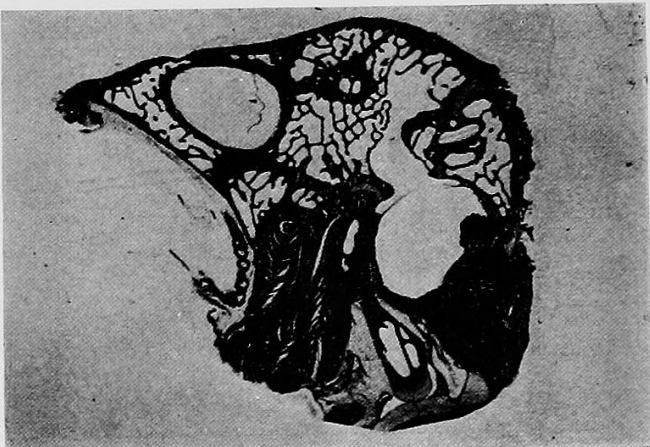

4. 切圧 60 回(娜孚化後 67 日)

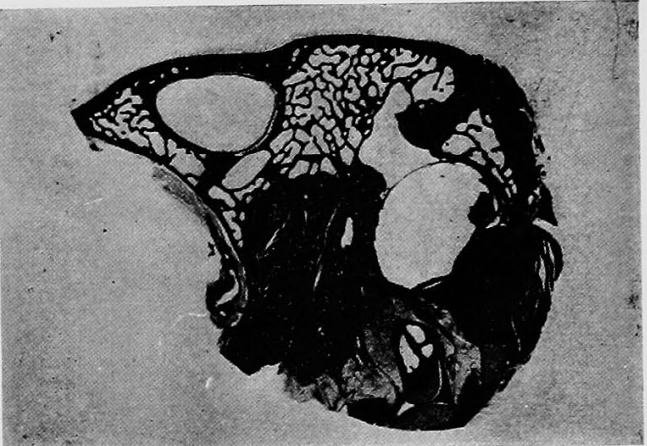

6. 減圧 60 回（卯孚化後 67 日） 
対照群，㲹圧翻及び減圧群にお゙ける䗋窠隔壁の上皮及び筲梁の状況

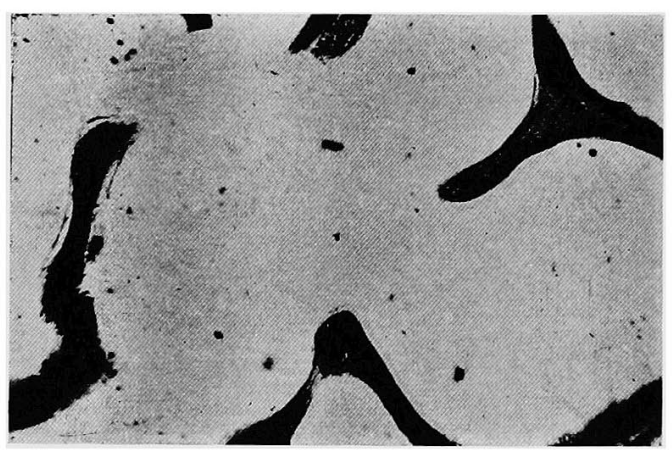

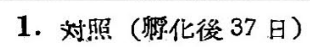

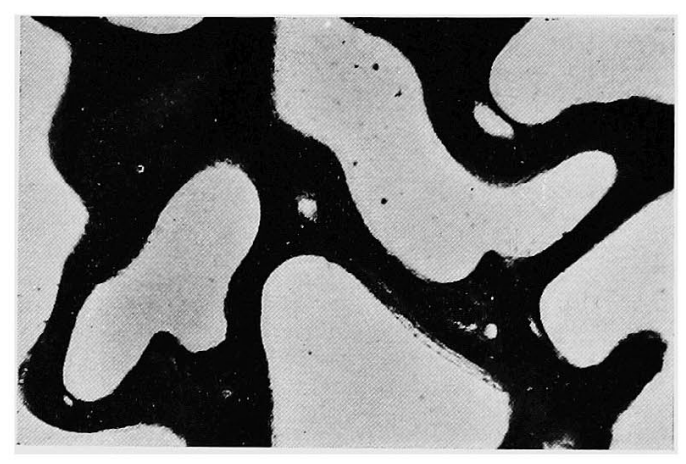

3. 加圧 30 回（睬化後. 37 日)

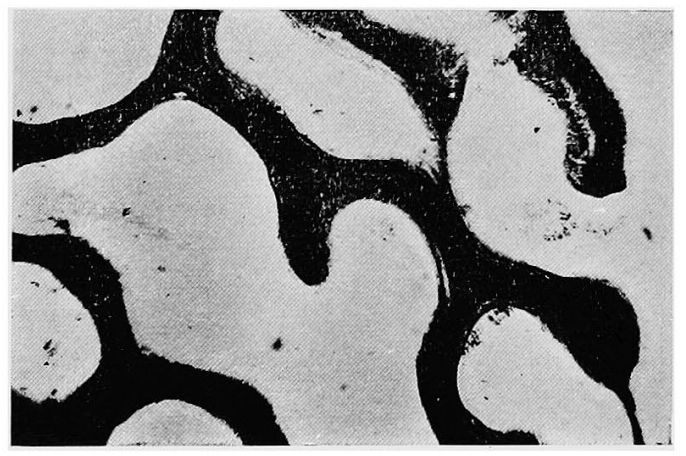

5. 娍圧 30 回（船化後 37 日）

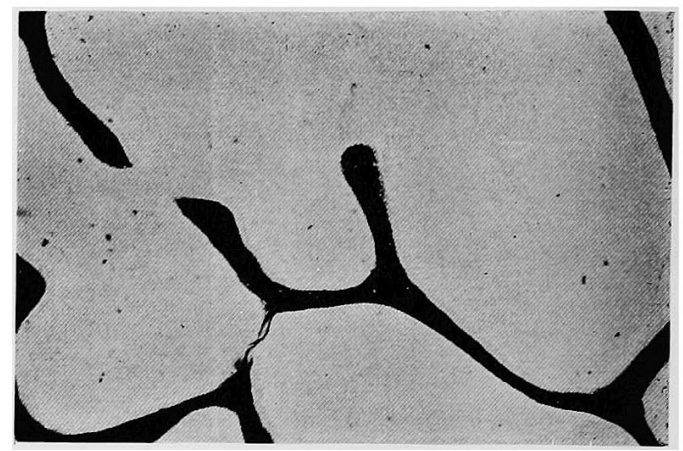

2. 刘热 (那化後 67 日)

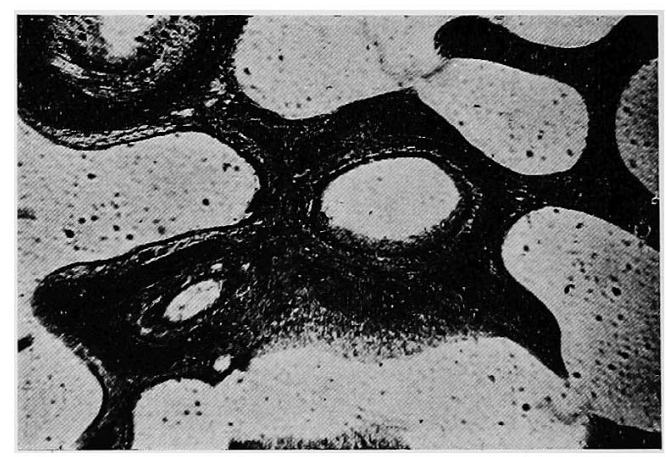

4. 测圧 60 回（那化後 67 日）

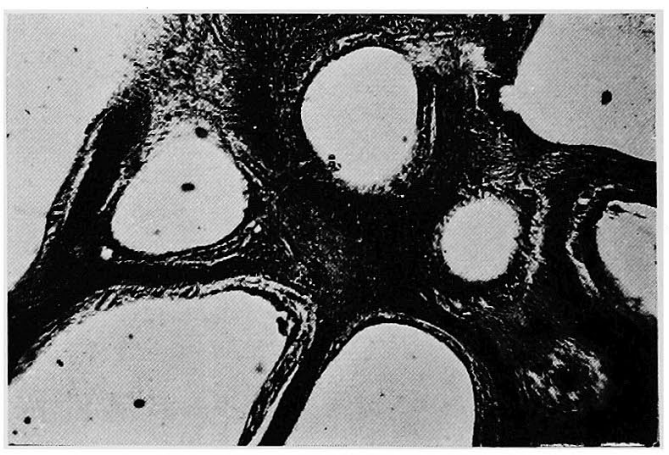

6. 娍圧 60 回 (解化後 67 日) 


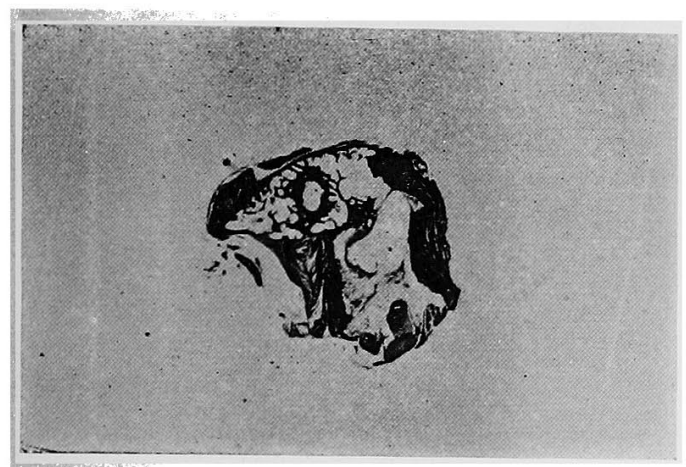

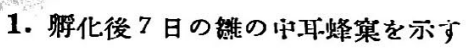

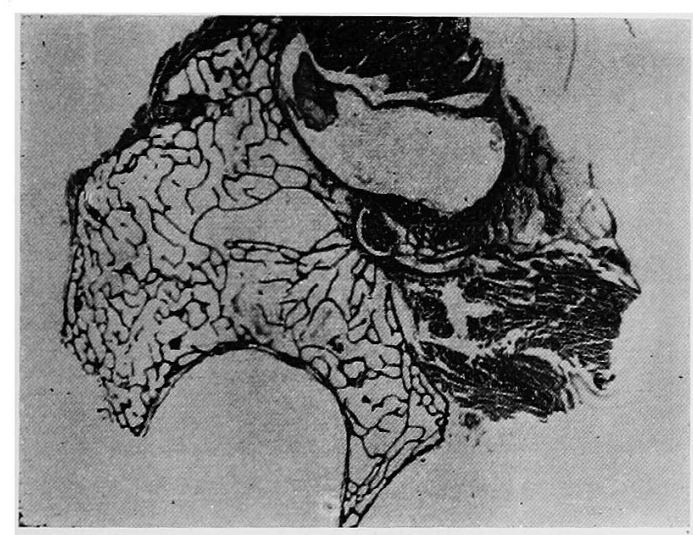

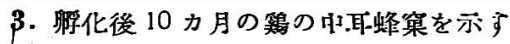

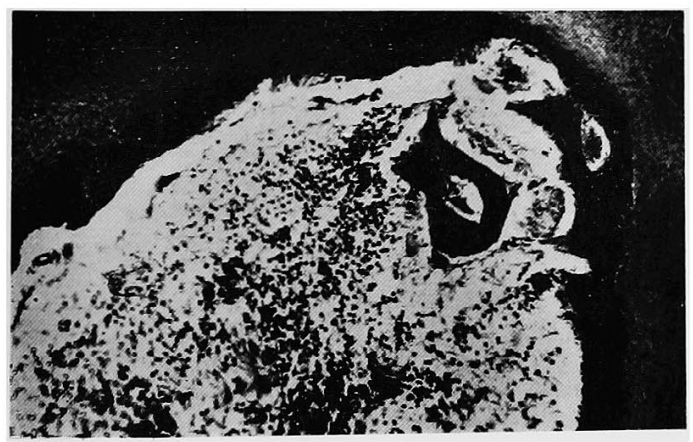

5. 加圧 30 回（馴化後 37 日）の跳の頭盖琶面 に゙まける綜維化されつろある原㕸铕堅を示す

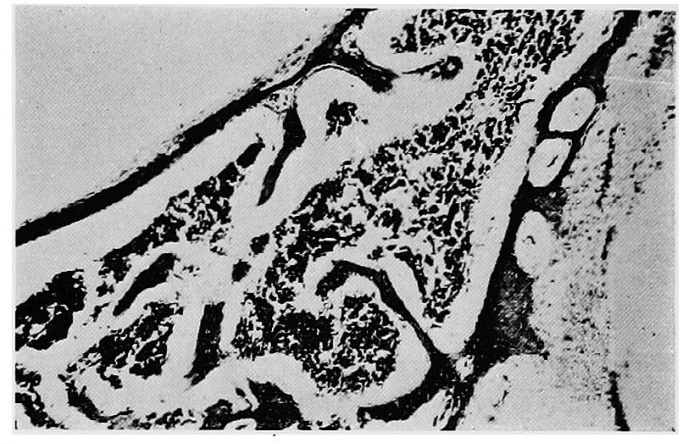

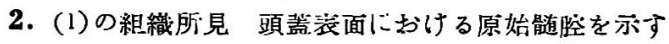

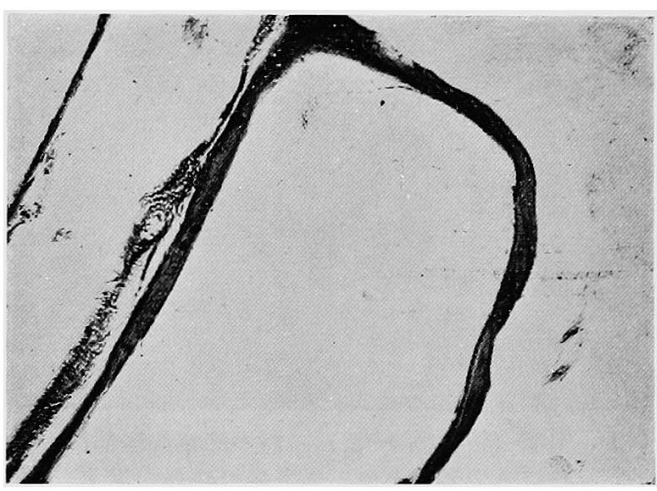

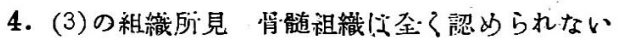

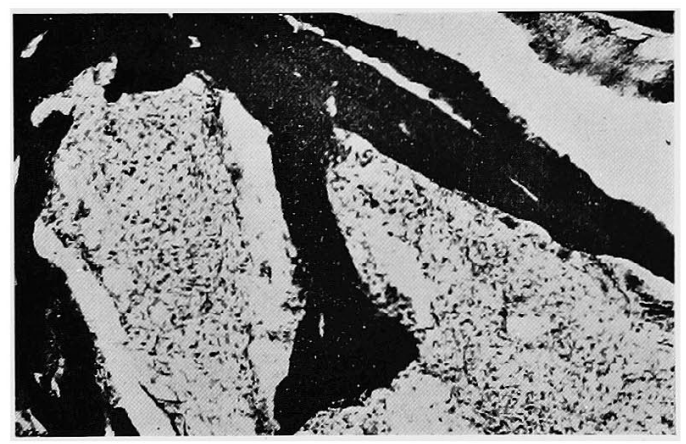

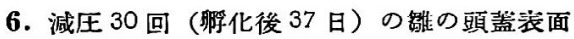
にちする綜維能を示す 


\section{小川論 交附図 ( N )}

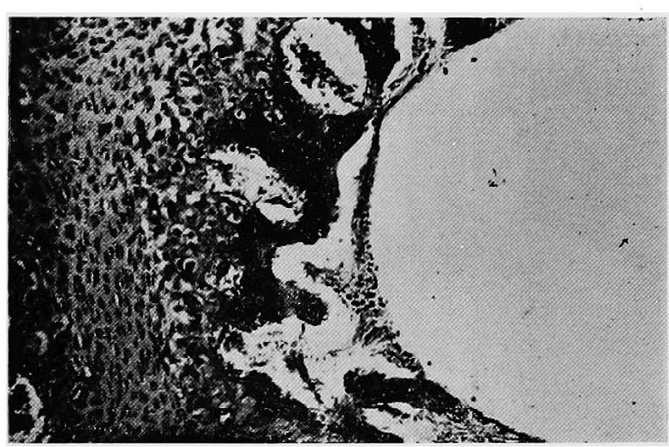

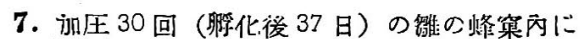

おける化筒現象の遅延した軟筒租織の龍分を示す

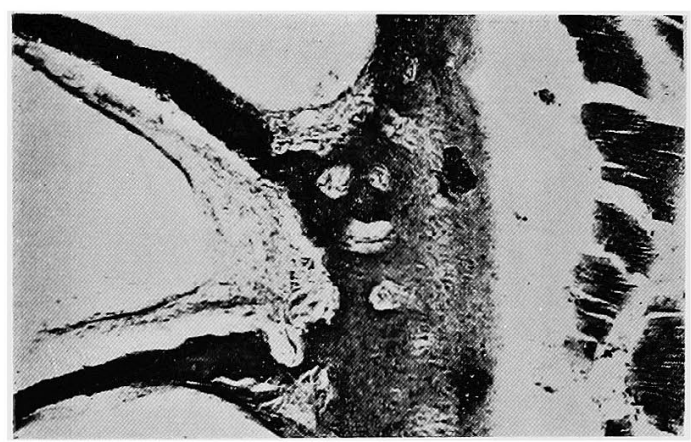

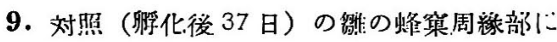
おける纤装な上皮下綃公繶の牫存を示す

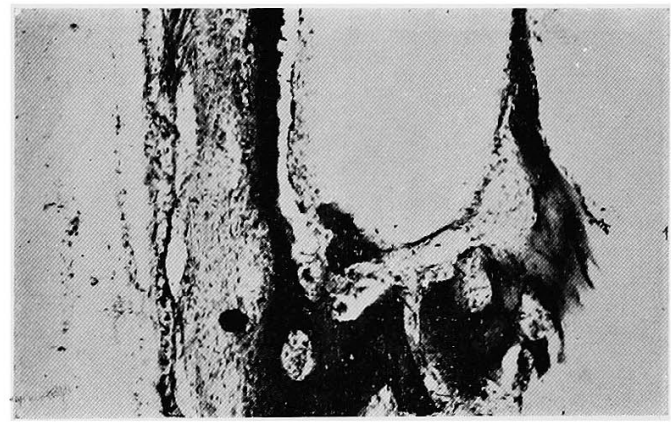

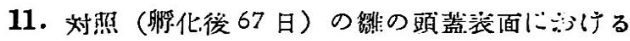
蜂㮤に湎する上皮下に党状吸收破留細胞及び 遊離有店を亦方

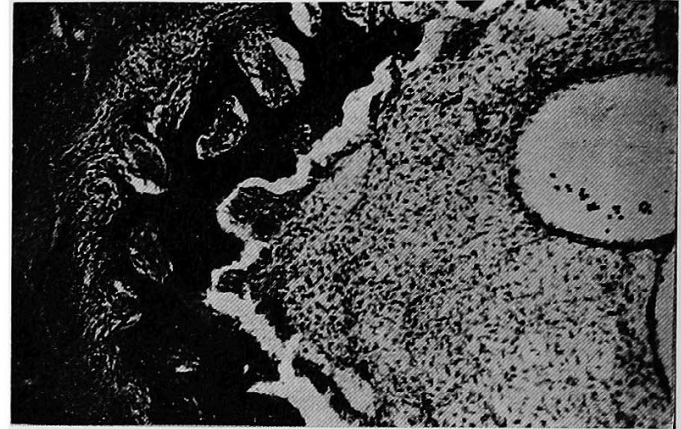

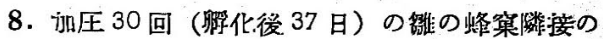
線維髄の含気化されつろかる所見を六り

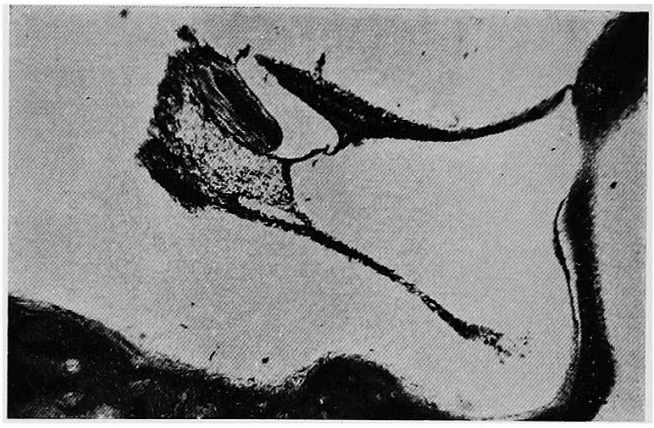

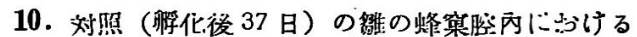
遊離霄片と拥胞浸潤を示y

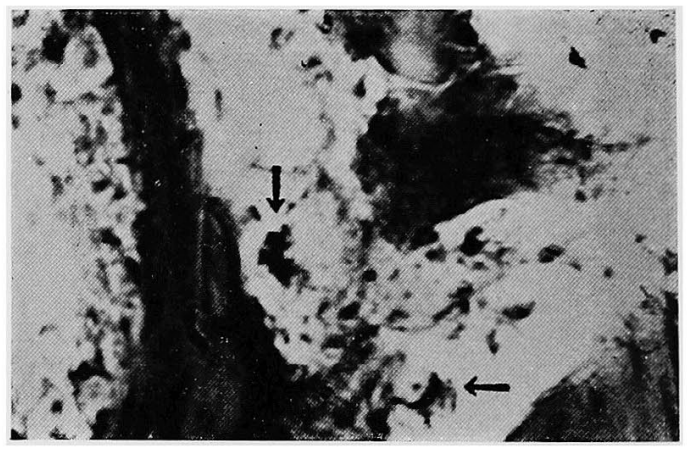

12.（11）の强拡大

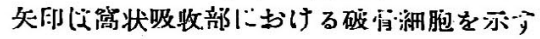




\section{小川論文附図 (V)}

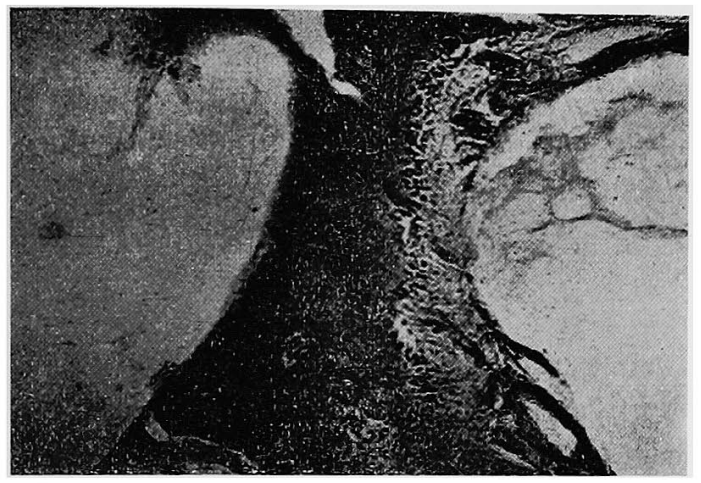

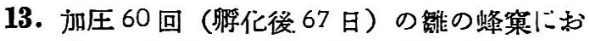
ける上皮下租織の肥厚及び骨梁に唼する造 管科胞の橧殖を示す

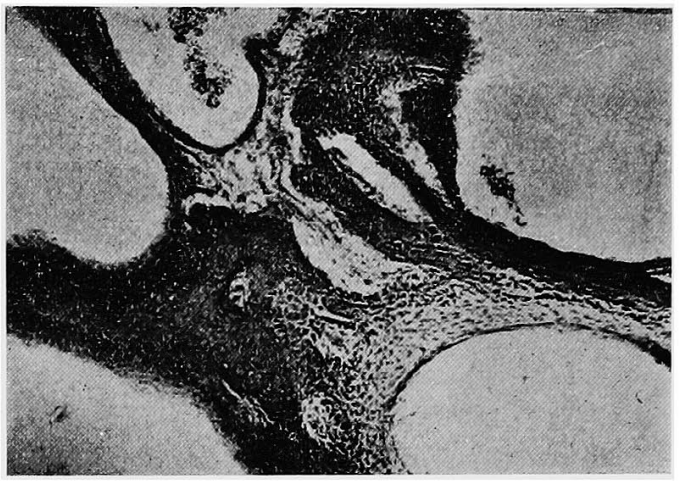

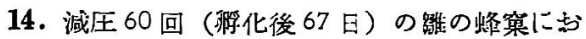
ける軟骨租織の残存区び遅延せる化霄含気 化墭枟を示方 